\title{
FEJLESZTŐPROGRAMOK EGYMINTÁS LONGITUDINÁLIS VIZSGÁLATÁNAK MATEMATIKAI STATISZTIKAI HÁTTERE
}

Szerzők:

Mező Ferenc

Debreceni Egyetem

Máth János

Debreceni Egyetem

Abari Kálmán

Debreceni Egyetem

Mező Katalin

Debreceni Egyetem

\section{Lektorok:}

Demetrovics János

Eötvös Lóránd Tudományegyetem

Koncz István

Professzorok az Európai Magyarországért

Szilágyi Barnabás

Debreceni Egyetem

Nemes Magdolna

Debreceni Egyetem

Első szerző e-mail címe:

ferenc.mezo1@gmail.com

Mező F., Máth J., Abari K. és Mező K. (2016): Fejlesztőprogramok egymintás longitudinális vizsgálatának matematikai statisztikai háttere. Különleges Bánásmód, II. évf., 2016/1. szám, 63-72. DOI 10.18458/KB.2016.1.63

\begin{abstract}
Absztrakt
E tanulmány a különleges bánásmódot igénylö tanulók számára készült fejlesztőprogramok egymintás, longitudinális (például ugyanazt a tanulócsoportot évente felmérö, nyomon követéses jellegü) hatásvizsgálatának matematikai statisztikai elemzéséhez kínál módszertani útmutatót. Praktikus segítséget nyújtunk a különbségvizsgálatok matematikai statisztikai számításainak kiválasztásához, a számítások elvégzésére alkalmas $R$ statisztikai szoftverbe irható parancssorokhoz, az $R$ által végrehajtott számítások eredményeinek értelmezéséhez, szövegbe foglalásához.
\end{abstract}

Kulcsszavak: fejlesztőprogram, hatásvizsgálat, statisztika

Diszciplinák: matematika, pszichológia, gyógypedagógia, pedagógia

\begin{abstract}
MATHEMATICAL STATISTICAL BACKGROUND OF ONE SAMPLED LONGITUDINAL STUDY OF DEVELOPMENT PROGRAMMES

This paper offers a methodological guidance to mathematical statisctical analysis of one sampled longitudinal studies of development programmes. After summarising the basic terms we: a) show a simple algorhitm to choice adequate statistic tests, b) present $R$ commands of these statistic tests (note: $R$ is a downloadable free software), and c) give suggestions about how we can interpret the results of statistical calculations done by this software.
\end{abstract}

Keywords: development programmes, effectiveness study, statistics, R language

Disciplines: mathematics, psychology, special education, pedagogy 
A különleges bánásmódot igénylö (sajátos nevelési igényü és/vagy beilleszkedési, tanulási, magatartási zavaros és/vagy tehetséges) tanulókra fókuszáló fejlesztőprogramok hatásvizsgálata (kontrollcsoport alkalmazása nélkül is) megvalósulhat:

a) a fejlesztési tervben foglalt adott kritériumszinthez történő viszonyítással (Mező és tsai, 2015a);

b) elővizsgálat-fejlesztés-utóvizsgálat elrendezésben (Mező és tsai, 2015b);

c) nyomon követéses módon, longitudinális vizsgálat keretében (1. ábra) - jelen tanulmányban erre az esetre fókuszálunk a továbbiakban.

1. ábra: különbségvizsgálaton alapuló egymintás (vagy: összetartozó mintás) nyomon követéses hatásvizsgálat sémája: ugyanazzal a csoporttal ugyanazokat a vizsgálatokat vesszük fel különbözö alkalmakkor (forrás: Mezö F.)

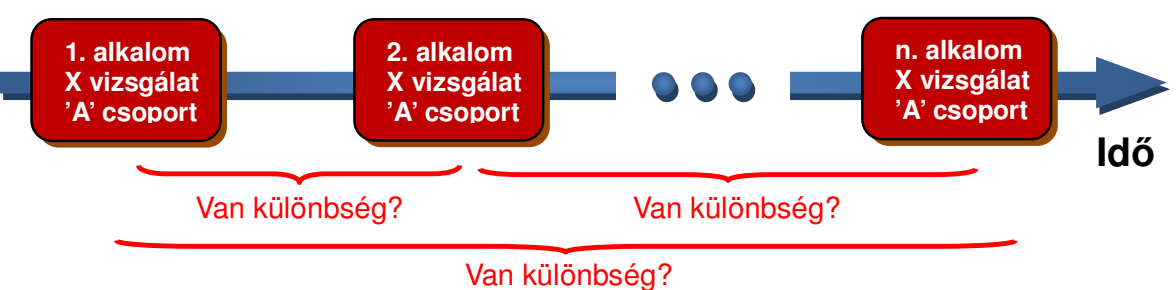

Nyomon követéses hatásvizsgálattal találkozunk például olyankor, amikor az alábbiakhoz hasonló kérdésekre kell matematikai statisztikai eljárásokkal bizonyított választ adnunk:

a) Vizsgálatunkban arra voltunk kíváncsiak, hogy az „IPOO - minimum program” (Mezö, 2011, Dávid, 2006) tanulás módszertani tréning előtt és után, illetve egy évvel a tréning után mért tanulás módszertani teljesítményben (a Jupiterbolha-próba összpontszámában) jelentős különb-ség tapasztalható-e? Különösen: kedvező (itt: teljesítményt növelő) hatása volt-e a tréningnek, vagy sem?

b) Vizsgálatunkban arra voltunk kíváncsiak, hogy tanulóink az „IPOO-minimum program” előtti osztályzataikhoz képest lényegesen jobb osztályzatokat kapnak-e a tréning után közvetlenül, illetve egy év múlva, olyan tananyagokból adott feleleteikre, amelyekkel kapcsolatban vélhetően minimális előzetes tudásuk volt, s saját maguknak kellett a tananyagot feldolgozni?

c) Egy fejlesztőprogramban három éven keresztül kísérjük figyelemmel a ló-asszisztált foglalkozásokra (Schéder, 2015) koncentráló táborba jelentkezők számát. A diákok például 2014-ben kerültek be a programba, s ekkor regisztráltuk először, hogy jelentkeztek-e a táborba vagy sem. 2015-ben és 2016-ban is regisztráltuk a jelentkezőket. Azt vizsgáltuk, a jelentkezések gyakoriságai mutatnak-e változást a három év folyamán?

E kérdések közös vonása: egy csoport kettőnél több vizsgálati alkalommal nyert eredményét hasonlítjuk össze (nyomon követéses vizsgálatot végzünk). Az alábbiakban egyrészt a különböző alkalmakkal végzett mérések eredményeinek összehasonlításához szükséges matematikai statisztikai próbák kiválasztásának algoritmusára fókuszálunk, másrészt e próbák elvégzését segítő, ingyenesen letölthető szoftver (az R statisztikai programcsomag) idevágó parancsaira és a szoftver outputjaként megjelenő statisztikai eredmények interpretációjára nyújtunk példákat. A tanulmány olvasásához szükséges minimális matematikai statisztikai 
ismeretek (pl. minta, hipotézis, szignifikancia, eloszlás, nominális, ordinális, kvantitatív változók) összefoglalója megtalálható Máth és tsai. (2015) müvében. A tudományos és statisztikai következtetés alapjaival kapcsolatban Dienes (2013) ad átfogó elemzést. Az Rnyelvvel kapcsolatos összefoglalót pedig Abari és tsai. (2015) és Solymosi (2005) közölnek.

E módszertani útmutatóban az $\mathrm{R}$ parancsokkal kapcsolatban a következő jelöléseket vezetjük be (vö.: Abari, 2008) az adatbázisok (lásd: 2. ábra) kapcsán:

\section{2. ábra: széles és hosszú szerkezetü adattáblák (forrás: a Szerzők)}

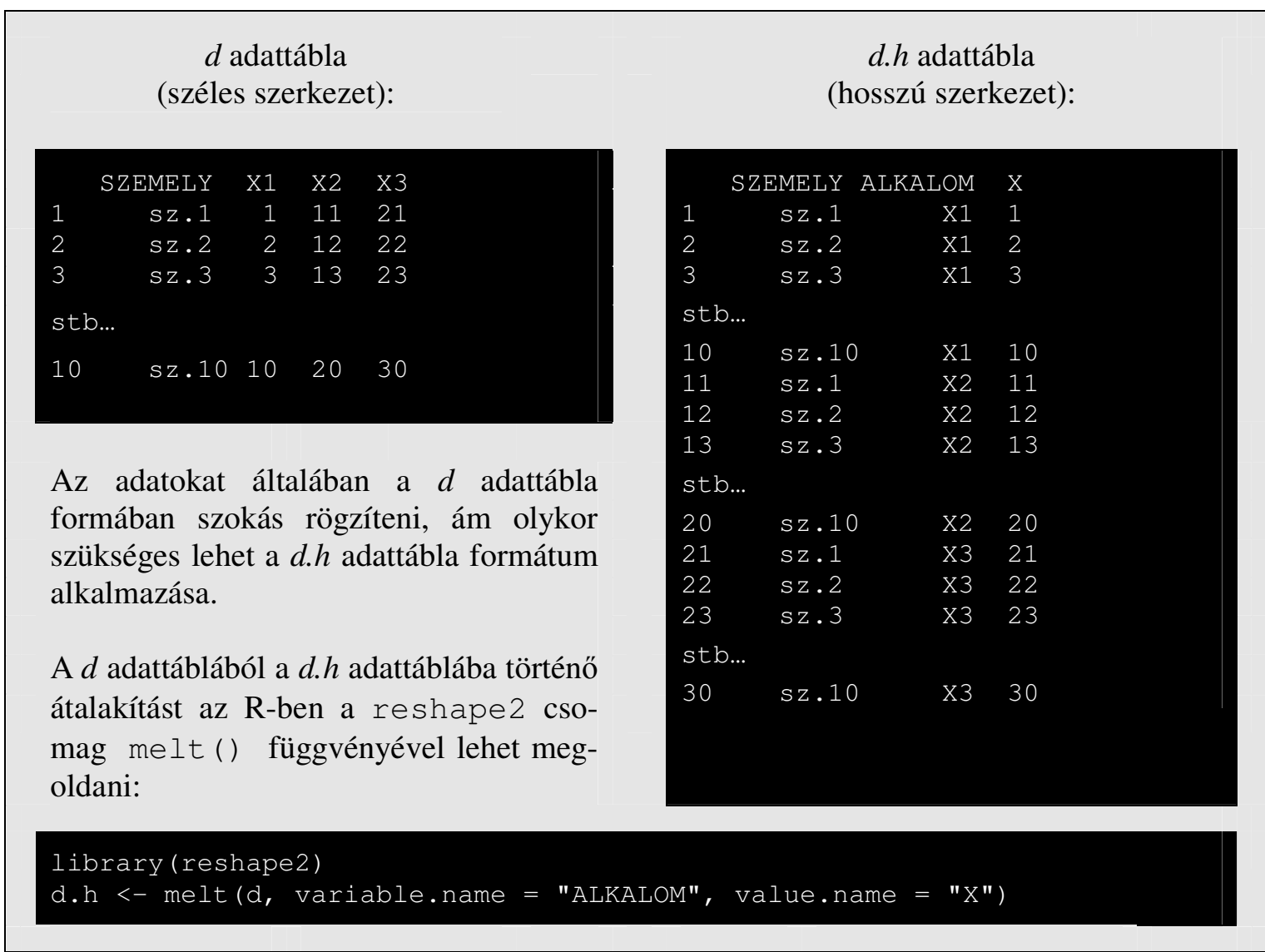

- $d$ : egy $d$ nevü adattábla neve, melyben valamennyi személy adata egyetlen sorban szerepel, még akkor is, ha több különbözö mérés tartozik hozzá. Az adattábla oszlopai a vizsgált változók (pl. Xl vagy „IQ” stb. változók) adatait tartalmazzák. Az ilyen szerkezetü adattáblákat szélesnek nevezzük. Példa: 2. ábra $d$ adatbázisa, melynek oszlopai a vizsgált változók ( $X 1, X 2, X 3$ stb. mint mondjuk az 1., 2., 3. stb. osztályos korban mért eredmények) adatait tartalmazzák, a SZEMELY oszlopban pedig a vizsgált személyek azonosítói jelennek meg Az azonos személyek különböző mérési időpontok közötti összetartozását $X 1, X 2, X 3$ stb. nevekkel jelöljük, így ezek a változók az R parancsokban $d \$ X 1, d \$ X 2$, illetve $d \$ X 3$ módon jelennek meg (pl. $X 1=$ első osztályos korban mért teljesítmény, $X 2=$ második osztályos korban mért teljesítmény, $X 3$ = harmadik osztályos korban mért teljesítmény; a $d \$ X 1$ jelentése pedig: $d$ adatbázis $X 1$ változójára hivatkozunk az $\mathrm{R}$ parancsban, stb.). 
- $\quad$ d.h: néhány statisztikai próba (például a Bartlett-próba vagy az összetartozó mintás egyszempontos varianciaanalízis) esetében a $d$ adatbázist át kell alakítanunk jelen tanulmányban $d$.h-nak nevezett ún. hosszú formátumba, annak érdekében, hogy az egy személyhez tartozó $n$ számú mérés $n$ számú külön sorban szerepeljen (lásd: 2 . ábra $d . h$ adatbázisát). A d.h adatbázis formátumában az az elv érvényesül, hogy ,az azonos változóhoz tartozó adatértékek kerüljenek azonos oszlopba”. Az R-ben a reshape2 csomag melt () függvényével van lehetőség arra, hogy a $d$ adattábla szerkezetét áttranszformáljuk át a $d . h$ adattábla hosszú struktúrájába.

\section{Statisztikaválasztás és végrehajtás az R-nyelvben}

Az egymintás nyomon követéses jellegü, s a különböző időpontokban gyüjtött adatok különbségeire fókuszáló hatásvizsgálatokhoz szükséges matematikai statisztikai próba kiválasztásának menete röviden a következö (vö.: 3. ábra):

1. Döntenünk kell arról, hogy nominális, ordinális, vagy kvantitatív változókkal kell-e számolnunk (vö.: Máth és tsai, 2015).

2. Kvantitatív változók esetében az R-nyelv segítségével döntjük el, hogy: a) normális eloszlásúnak tekinthető (harang alakú görbét mutató) változókról van-e szó; b) a változók szórása közel egyformának tekinthetö-e.

3. Kizárólag e két lépés végrehajtását követően kerülhet megválasztásra, végrehajtásra a megfelelő statisztikai próba.

4. Időnként azonban további elemzésekre is szükség lehet.

A továbbiakban a változók kvantitatív, ordinális, nominális jellege alapján tekintjük át a szükséges R parancsokat, s szignifikancia szinttől függő interpretációjukat.

\section{Kvantitatív változók a nyomon követéses vizsgálatokban}

A nyomon követéses vizsgálatokban szereplö kvantitatív változók esetében ellenőriznünk kell, hogy esetükben teljesül-e a normális eloszlás, illetve a szóráshomogenitás feltétele. Amennyiben e feltételek teljesülnek, akkor valóban építhetünk e változók kvantitatív jellegére, s (összetartozó mintás egyszempontos) varianciaanalízissel elemezhetjük adatainkat. Ha e két feltételnek csak egyike teljesül vagy egyike sem, akkor változóinkkal legfeljebb az ordinális változókkal végezhető matematikai statisztikai próba (esetünkben például a Friedman-próba) hajtható végre (lásd: jelen tanulmány következő alfejezetét). E két feltétel ellenőrzésének, illetve a varianciaanalízis alkalmazásának módja dióhéjban a következő:

Az eloszlásvizsgálat során arra a kérdésre kell választ kapnunk hogy „Az ugyanahhoz a dologhoz/személyhez tartozó, több (legalább 3) különböző időpontban/helyzetben mért XI (például a fejlesztés elején mért teljesítmény), X2 (mondjuk: a fejlesztés végén mért teljesít-

mény), X3 (például fejlesztés után egy évvel mért teljesítmény) stb. kvantitatív (függő) változók normális eloszlásúnak tekinthetők-e?". E kérdés megválaszolására alkalmas egyik statisztikai próba a Shapiro-Wilk-próba, melynek R-parancsa a következő:

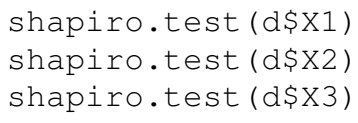


3. ábra: Statisztikaválasztás egymintás, nyomon követéses hatásvizsgálat esetében ( $d \$ X 1=$ elsö vizsgálat, $d \$ X 2=$ második vizsgálat, $d \$ X 3=$ harmadik vizsgálat adatait tartalmazó változók a „d” adatbázisban). Forrás: Mezö, Máth és Abari (2008) alapján Mezö F.

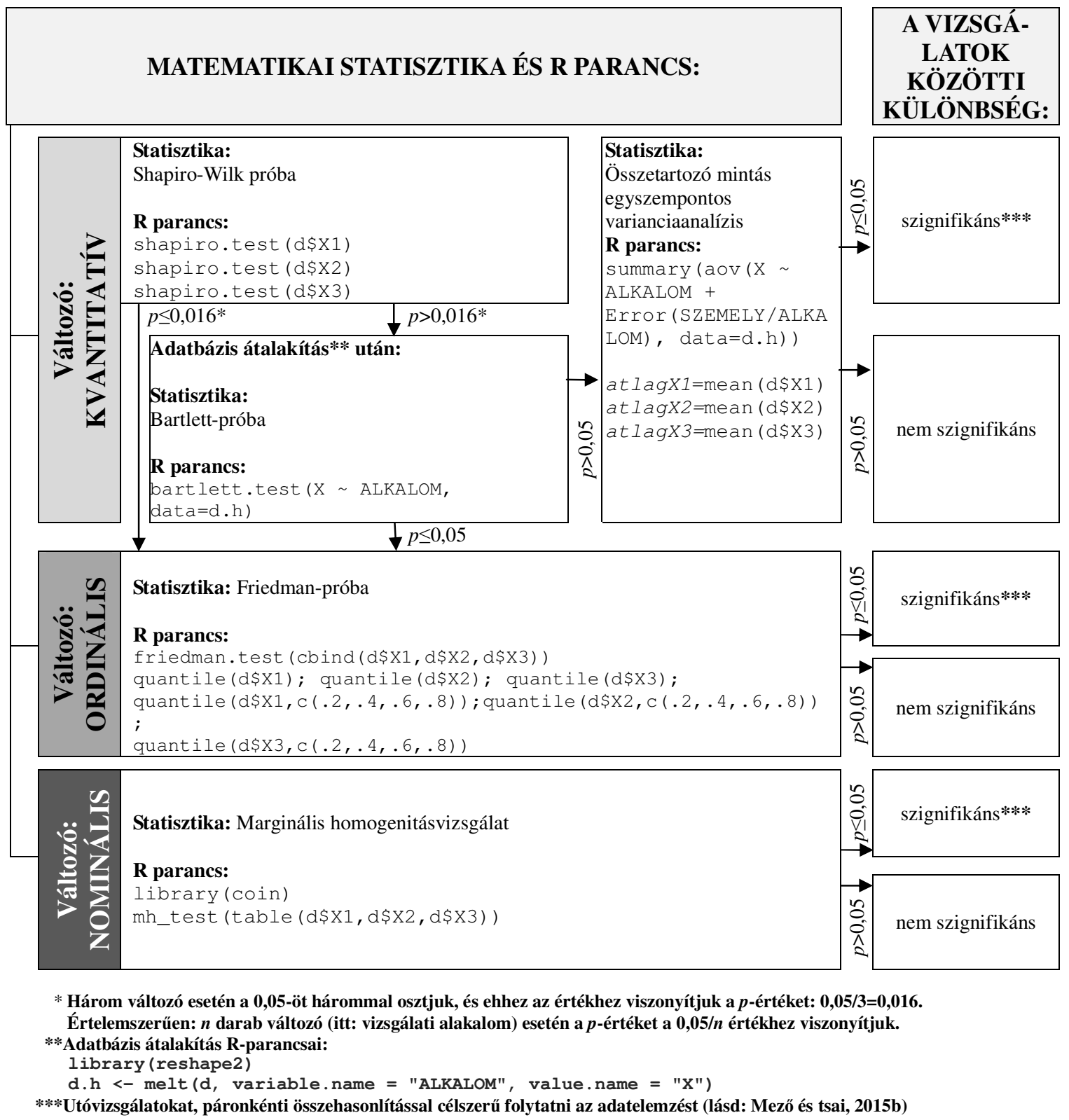

Mindez például így foglalható össze egy tanulmányban: „Vizsgálatunkban arra voltunk kíváncsiak, hogy az „IPOO - minimum program” tanulás módszertani tréning előtt és után, illetve egy évvel a tréning után mért tanulás módszertani teljesítményben (a Jupiterbolhapróba összpontszámában) jelentős különbség tapasztalható-e? Különösen: kedvező (itt: teljesítményt növelö) hatása volt-e a tréningnek, vagy sem? Az adekvát statisztikai próba kiválasztásához mindenekelőtt ellenőriznünk kellett azt, hogy a három mérési alkalom adatait tartalmazó változóink normális eloszlásúak-e. Ezt a Shapiro-Wilk próbával ellenőriztük, amelynek eredménye szerint..." 
A Shapiro-Wilk-próba eredményei és az $\mathrm{R}$ által megadott szignifikancia szint ( $p$-érték) alapján döntünk a további teendőinkről (fontos: a statisztikaválasztó döntésünket befolyásoló kritériumértéknek $0,05 / n$ értéket válasszunk, ahol $n=$ a vizsgált változók száma. Példánkban 3 mérési alkalom adatait tartalmazó 3 változó eloszlását vizsgáljuk, így kritériumszintünk $0,05 / 3=0,016$ lesz):

a) Ha a Shapiro-Wilk próba legalább az egyik változó esetében $p$-value $\leq 0,016$ értéket ad, akkor a változók között van nem normális eloszlású változó, és a fent megkezdett mondat pedig így folytatódhat: ,....nem teljesül, hogy mindegyik változó normális eloszlású (az első vizsgálat esetén $p=p$-value; a második vizsgálat esetén $p=p$-value; a harmadik vizsgálat esetén $p=p$-value).” A ,p-value” helyére az $\mathrm{R}$ által megadott $p$-értéket kell beírni. Mindez azzal a következménnyel is jár, hogy adataink, változóink nem alkalmasak varianciaanalízis végrehajtására, s az ordinális változók esetében alkalmazható statisztikai próbákhoz kell folyamodnunk (lásd e tanulmány következő alfejezetét).

b) Ha a Shapiro-Wilk próba mindhárom változó esetében $p>0,016$, akkor a változók eloszlása normálisnak tekinthető, s imént félbe hagyott mondatunk így fejezhető be: „...( $p=p$-value $)$ mindhárom változót normális eloszlásúnak tekinthetjük (az első vizsgálat esetén $\mathrm{p}=p$-value; a második vizsgálat esetén $p=p$-value; a harmadik vizsgálat esetén $p=p$ value). A továbbiakban meggyőződtünk arról is, hogy a különböző mérések alkalmával a szórások közel egyformák-e.” A ,p-value” helyére az $\mathrm{R}$ által megadott $p$-értéket kell beírni. Ebben az esetben az adatelemző munka következő lépéseként a szóráshomogenítás vizsgálata következhet.

A szóráshomogenitás azt jelenti, hogy az $X 1, X 2$ és $X 3$ változók szórása közel egyforma. A szóráshomogenitás vizsgálatára alkalmas egyik statisztikai próba a Bartlett-próba, amely esetében az $\mathrm{R}$ az úgynevezett hosszú szerkezetü (a további példáinkban $d . h$ néven hivatkozott) adattáblát kívánja meg (ennek az adattáblának a szerkezetét és előállításának R-parancsát a 2. ábra foglalja össze). A Bartlett-próba példánkhoz tartozó R parancsa a következő:

bartlett.test $(\mathrm{X} \sim \mathrm{ALKALOM}$, data $=\mathrm{d} . \mathrm{h})$

A Bartlett-próba esetében a 0,05-ös szignifikancia szinthez viszonyítjuk a $p$-értékeket, melyek az alábbiak lehetnek:

a) Ha a Bartlett-próba eredménye szerint $p$-value $\leq 0,05$, akkor változóink szórása nem tekinthető közel sem egyformának. Ezt így foglalhatjuk szövegbe például: „A szóráshomogenitás vizsgálatára Bartlett-próbát alkalmaztunk - ennek eredménye szerint ( $p=p$-value), a szóráshomogenitás feltétele nem teljesül.” Ez azzal jár, hogy adataink nem alkalmasak a varianciaanalízissel történő további elemzésre, s ehelyett inkább az ordinális változók esetében használható statisztikai próbák jöhetnek szóba (lásd: az ordinális változókkal kapcsolatos következő alfejezetet!).

b) Ha a Bartlett-próba eredménye szerint p-value > 0,05, akkor a szórások közel egyformának tekinthetők, s ezt a következőképpen interpretálhatjuk: „A szóráshomogenitás vizsgálatára Bartlett-próbát alkalmaztunk - ennek eredménye szerint ( $p=p$-value), a szóráshomogenitás feltétele teljesül.” Tekintettel arra, hogy ezt a próbát csak akkor végeztük el, ha a normalitásra vonatkozó feltétel is teljesült, ez az eredmény azzal jár, hogy adataink alkalmasak a varianciaanalízissel történő további adatelemzésre.

Összetartozó mintás egyszempontos varianciaanalízis alkalmával példánkban most lényegében azt ellenőrizzük, hogy az $X 1, X 2, X 3$ változók populáció átlagai egyenlők-e. A szükséges R-parancsok: 
summary (aov (X ALKALOM + Error (SZEMELY/ALKALOM), data=d.h))

at $\operatorname{lagX1}=$ mean $(d \$ X 1) ; \operatorname{atlagX2=mean~}(d \$ X 2) ; \operatorname{atlagX3=mean~}(d \$ X 3)$

Lehetséges eredmények:

a) Ha az összetartozó mintás egyszempontos varianciaanalízis eredménye szerint $p$-value $\leq$ 0,05 , akkor az $X 1, X 2, X 3$ változók populáció átlagai eltérők (különbség van a mérések között). Szövegbe foglalva: „Ennek ismeretében összetartozó mintás egyszempontos varianciaanalízist végeztünk, amelynek eredménye szerint: különbség van a különböző időpontokban mért teljesítmények között ( $\mathrm{p}=p$-value). A szignifikánsan eltérö átlagok a következők: atlagX1, atlagX2, atlagX3.” A változás növekvő vagy csökkenő jellegét a változók átlagai mutatják meg. Statisztikailag egzaktabb vizsgálat elvégzéséhez lásd (Vargha, 2000; Falus és Ollé, 2000; Reiczigel, Harnos és Solymosi, 2007).

b) Ha az összetartozó mintás egyszempontos varianciaanalízis eredménye $p$-value $>0,05$ értéket ad, akkor az $X 1, X 2, X 3$ változó populáció átlagai egyenlők (másképp: nem különböznek egymástól lényegesen). Lehetséges interpretáció: „Ennek ismeretében összetartozó mintás egyszempontos varianciaanalízist végeztünk, amelynek eredménye szerint: nincs különbség a különböző időpontokban mért teljesítmények között ( $\mathrm{p}=p$ value)"

\section{Ordinális változók a nyomon követéses vizsgálatokban}

$\mathrm{Az}$ ordinális változókkal folytatható vizsgálatokra akkor lehet szükségünk, ha vizsgált változóink: a) eleve ordinális skálájúak (például ötfokú skálán adott osztályzatok); b) kvantitatív skálájúak ugyan, ám nem felelnek meg a normalitás és a szóráshomogenitás fentebb közölt feltételeinek. Általános értelemben véve a következő kérdésre keressük a választ a nyomon követéses vizsgálat ilyen eseteiben: „Az ugyanahhoz a dologhoz/személyhez tartozó $X$ legalább oridnális (függő) változó értéke változik-e különböző időpontokban/helyzetekben (alkalom = független változó) történő mérésekkor?”. Ide vonatkozó példánk legyen a következő: „Vizsgálatunkban arra voltunk kíváncsiak, hogy tanulóink az „IPOO-minimum program” elötti osztályzataikhoz képest lényegesen jobb osztályzatokat kapnak-e a tanulás módszertani tréning után közvetlenül, illetve egy év múlva, olyan tananyagokból adott feleleteikre, amelyekkel kapcsolatban vélhetően minimális előzetes tudásuk volt, s saját maguknak kellett a tananyagot feldolgozni?"

Az adatelemzéshez használható itt tárgyalt statisztikai próba a Friedman-próba, mely arra a kérdésre ad választ, hogy az $X 1, X 2, X 3$ változók populáció mediánjai egyenlők-e. A Friedman-próba R-parancsa esetünkben:

$$
\text { friedman.test (cbind ( } d \$ x 1, d \$ x 2, d \$ x 3) \text { ) }
$$

A Friedman-próba lehetséges eredményei az alábbiak lehetnek:

a) Ha a Friedman-próba eredménye szerint $p$-value $>0,05$, akkor az $X 1, X 2, X 3$ változók populáció mediánjai egyenlők. Vagyis nyomon követéses vizsgálatunkról szóló prezentációnkban megfogalmazhatjuk, hogy: „A Friedman-próba eredménye szerint nincs szignifikáns különbség ( $p=p$-value) a különbözö alkalmakkal felvett tesztek eredménye között."

b) Ha a Friedman-próba eredményeként $p$-value $\leq 0,05$ értéket kapunk, akkor az arra utal, hogy az $X 1, X 2, X 3$ változók populáció mediánjai nem egyenlök. Ezt az eredményt például ekképpen foglalhatjuk szavakba: „A Friedman-próba eredménye szerint 
szignifikáns különbség ( $p=p$-value $)$ van a különböző alkalmakkal felvett tesztek eredménye között." Ismertessük és értelmezzük a különbséget! Az értelmezésben segíthet, ha leíró statisztikákat kérünk az $X 1, X 2, X 3$ változókról. Kérhetünk kvartiliseket (melyek a mintát negyedelik), de kérhetünk részletesebb ábrázolást is. A kvartiliseket vagy a mintát ötödölő értékeket (kvantiliseket) a következő $\mathrm{R}$ parancsokkal kaphatjuk meg:

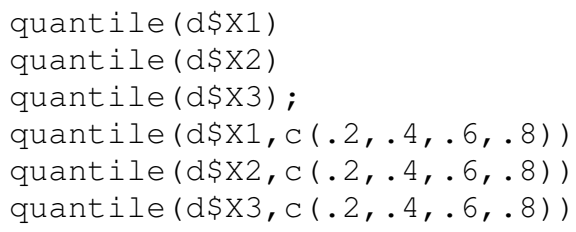

\section{Nominális változók a nyomon követéses vizsgálatokban}

A nyomon követéses vizsgálatokban a nominális (tehát az egymástól megkülönböztethetö, de nem sorbarendezhető értékekekkel rendelkező) változók esetében feltehető általános jellegü kérdés lehet például: „Ugyanahhoz a személyekhez/dologhoz tartozó $X 1, X 2, X 3$ nominális változó megfigyelt gyakoriságai eltérnek-e egymástól, azaz van-e változás?”.

Tegyük fel például, hogy jelen tanulmány elején felvetett ló-asszisztált foglalkozásokat (Schéder, 2015) tartalmazó nyári táborba jelentkezők számának alakulását kívánjuk nyomon követni 2014-2016. között, három éven keresztül. Jelentse $X 1=$ a nyári táborba történő jelentkezések 2014. évi számát ( $1=$ jelentkezett; $2=$ nem jelentkezett), $X 2=$ a nyári táborba történő jelentkezések 2015. évi számát ( $1=$ jelentkezett; $2=$ nem jelentkezett), $X 3=$ a nyári táborba történő jelentkezések 2016. évi számát (1=jelentkezett; $2=$ nem jelentkezett). Ezt megfogalmazhatjuk így is: „Egy ló-asszisztált foglalkozásokra építő nyári tábor jellegü fejlesztő programban három éven keresztül kísértük figyelemmel a táborba jelentkezők számát. A diákok 2014-ben kerültek be a programba, s ekkor regisztráltuk először, hogy jelentkeztek-e a táborba vagy sem. 2015-ben és 2016-ban is regisztráltuk a jelentkezőket. Azt vizsgáltuk, hogy a jelentkezések gyakoriságai mutatnak-e változást a három év folyamán?”.

Az X1, X2 és X3 nominális változók gyakoriságának hasonlóságára vonatkozó kérdés megválaszolására alkalmas statisztikai próba lehet a marginális homogenitásvizsgálat, melynek R parancsa (mivel e próba végrehajtásához szükséges függvény az $\mathrm{R}$ programon belül a coin csomagban található, az mh_test() függvény hívása elött ki kell adnunk a library (coin) parancsot):

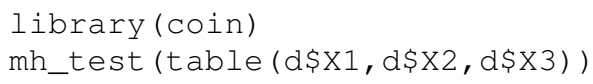

Ha a marginális homogenitásvizsgálat eredménye $p$-value $>0,05$, az arra utal, hogy az X1, $X 2, X 3$ változók gyakoriságai hasonlók. Ennek egy lehetséges megfogalmazása az adott példa kontextusában: „Marginális homogenitás teszttel vetettük össze a három időpontban megállapított jelentkezési gyakoriságokat és lényeges eltérést nem találtunk ( $p=p$-value)."

Amennyiben a marginális homogenitásvizsgálat $p$-value $\leq 0,05$ szinten szignifikáns különbséget jelez $X 1, X 2, X 3$ változók gyakoriságai között, akkor egyrészt szövegbe foglalva ilyesmit állapíthatunk meg: „Marginális homogenitás teszttel vetettük össze a három időpontban megállapított jelentkezési gyakoriságokat és lényeges eltérést találtunk $(p=p$ - 
value); márészt közöljük mindhárom mérés esetén a változók gyakoriságait a table ( $\mathrm{d} \$ \mathrm{X} 1)$, table $(d \$ \times 2)$ és table $(d \$ \times 3)$ parancsokkal hogy a változás lényegét demonstrálhassuk és értelmezhessük!

Kategórikus változók elemzésével kapcsolatban lásd még: Máth (2004).

\section{Zárógondolatok}

Jelen tanulmányban a fejlesztőprogramok hatásvizsgálatának arra a sepciális esetére fókuszáltunk, amelyben egy csoport három vagy több alkalommal azonos módon/eszközzel gyüjtött adatait vetjük össze egymással. Ezzel kapcsolatban öt matematikai statisztikai próba és Rnyelvbeli parancsaikat tekintettük át:

- Shapiro-Wilk-próbát alkalmaztunk a három (vagy több) vizsgálat során gyüjtött adatok normális eloszlásának vizsgálata céljából.

- Bartlett-próbával teszteltük a három (vagy több) vizsgálati alkalom során gyűjtött adatok szóráshomogenitását.

- Összetartozó mintás egyszempontos varianciaanalízist alkalmaztunk a normális eloszlás és a szóráshomogenitás feltételeinek megfelelő kvantitatív változók elemzése érdekében.

- Friedman-próbával teszteltük a három (vagy több) alkalommal gyüjtött adatok esetében a mediánok hasonlóságát.

- Marginális homogenitásvizsgálatot használtunk a nominális változók gyakoriságainak hasonlóságának elemzése céljából.

Fontos tudni, hogy más statisztikai próbák, módszerek (lásd: Varga, 2000) és vizsgálati elrendezések (Eccles és tsai, 2003) is léteznek hasonló kérdések eldöntésére.

A nyomon követéses, longitudinális vizsgálatok eredményeinek értelmezésekor (s a hatásvizsgálat korlátai között) célszerü figyelembe venni olyan lehetséges torzító tényezőket, mint a sorozathatások és az idői hatások (Szokolszky, 2004). A sorozathatások eredményei lehetnek például a gyakorlatlanságból eredő kezdeti relatív gyenge kiinduló eredmények, vagy az első vizsgálat tapasztalatai alapján kialakult válaszadói beállítódások. Az idői hatások megnyilvánulhatnak többek között az adatgyüjtések közötti időszak ellenőrizetlen történéseiben (például a vizsgált fejlesztőprogram mellett öt másik hasonló célú fejlesztőprogramban történő részvétel esetében), a spontán érés hatásában (nem a fejlesztőprogram eredménye a különböző alkalmakkal mért teljesítménybeli változás, hanem a belső érési folyamatoké), vagy a vizsgálati személyek időközben történő (kilépés, utolérhetetlenség, esetleg elhalálozás miatt történő) lemorzsolódásában.

A fejlesztőprogram hatását a fentieken túlmenően jellemezheti az is, hogy a fejlesztendő terület különböző kezdeti jellemzőivel bíró személyek (például az eleve gyengébb vagy jobb képességüek - például a vizsgálati csoporto alsó és felső 25\%-ába sorolható személyek) eltérő módon reagálnak-e a programra. Ebböl a szempontból a csoportok közötti különbségvizsgálatok (Mező, Máth és Abari, 2008) mellett kapcsolatvizsgálatokat (például korrelációszámítást) is célszerű végezni a kezdeti értékek és a fejlődés mértéke (= a fejlesztés végén tapasztalt értékekböl kivont kezdeti értékek) között. Ilyen esetben például az erős pozitív korreláció arra utalhat, hogy a kezdetben eleve magasabb pontszámmal jelelmezhető személyek esélyesebbek a (pontszámokban kimutatható) nagyobb fejlődésre. Egy erős negatív korreláció pedig azt jelezheti, hogy a kezdeti mérés során gyenge eredményt elérők esetében valószínübb a nagyobb értékü pontszámnövekedés.

A fejlesztőprogramok hatásvizsgálatába mindössze egyetlen csoportot bevonó esetek - lásd: Mező és tsai $(2015 a, b)$, illetve jelen tanulmányt - mellett léteznek két vagy több csoportot egy vagy több alkalommal vizsgáló esetek is, melyeket a Különleges Bánásmód folyóirat további számaiban foglalunk össze. 


\section{Irodalom}

Abari K. (2008). A tehetségdiagnosztika adatkezelésbeli alapjai R környezetben. In Mező F. (szerk.). Tehetségdiagnosztika. Kocka Kör \& Faculty of Central European Studies, Constantine the Philosopher University in Nitra, Debrecen. pp 105-130.

Abari K., Mező F., Mező K. és Máth J. (2015). Fejlesztőprogramok hatásvizsgálatát szolgáló adatbázisok szerkezete egy ingyenes statisztikai szoftverben: az R-ben. Különleges Bánásmód, I. évf. 2015/2. szám, 37-47. DOI 10.18458/KB.2015.2.37

Dávid M. (2006): A tanulási kompetencia fejlesztése - elméleti háttér. Alkalmazott pszichológia, 2006. VIII. évfolyam, 1. szám, 51-64.p

Dienes Z. (2013). Mitöl tudomány a pszichológia? A tudományos és statisztikai következtetés alapjai. Akadémiai Kiadó, Budapest.

Eccles, M., Grimshaw, J., Cambell, M. és Ramsay, C. (2003). Research designs for studies evaluating the effectiveness of change and improvement strategies. Quality and Safety in Health Care, 2003, 12, 47-52 DOI: 10.1136/qhc.12.1.47

Falus I. és Ollé J. (2000). Statisztikai módszerek pedagógusok számára. Okker Kiadói Kft., Budapest.

Máth J. (2004). Kategórikus változók elemzése (loglineáris modell látens változókkal). Alkalmazott Pszichológia, VI/1, pp 57-81. Letöltés: 2015.09.14. Web: http://psycho.unideb. $\mathrm{hu} /$ archivum/kategorikus_valtozok.pdf

Máth J., Mező F., Abari K. és Mező K. (2015). Fejlesztőprogramok hatásvizsgálatának matematikai statisztikai alapfogalmai. Különleges Bánásmód, I. évf. 2015/1. szám, 69-77. DOI 10.18458/KB.2015.1.69

Mező F. (2011). Tanulás: diagnosztika és fejlesztés az IPOO-modell alapján. K+F Stúdió Kft., Debrecen.

Mező F., Máth J. és Abari K. (2008). A különbségvizsgálatokon alapuló tehetségdiagnosztika matematikai statisztikai alapjai (adatelemzési útmutató). In Mező F. (Szerk.). Tehetségdiagnosztika. Kocka Kör \& Faculty of Central European Studies, Constantine the Philosopher University in Nitra, Debrecen. pp 131-207.

Mező F., Máth J., Abari K. és Mező K. (2015a). Fejlesztőprogramok egymintás, kritériumorientált hatásvizsgálatának matematikai statisztikai háttere. Különleges Bánásmód, I. évf. 2015/3. szám, 69-78. DOI 10.18458/KB.2015.3.69

Mező F., Máth J., Abari K. és Mező K. (2015b): Fejlesztőprogramok önkontrollos hatásvizsgálatának matematikai statisztikai háttere. Különleges Bánásmód, I. évf. 2015/4. szám, 65-75. DOI 10.18458/KB.2015.4.65

Reiczigel J., Harnos A. és Solymosi N. (2007). Biostatisztika nem statisztikusoknak. Pars Kft., Nagykovácsi.

Schéder V. (2015). Különleges bánásmód ló-asszisztált foglalkozásokon. Különleges Bánásmód, I. évf. 2015/1. szám, 79-89. DOI 10.18458/KB.2015.1.79

Solymosi N. (2005). R<-...erre, erre...! Internetes R-jegyzet. Letöltés: 2015.09.14. Web: http://cran.r-project.org/doc/contrib/Solymosi-Rjegyzet.pdf

Szokolszky Á. (2004). Kutatómunka a pszichológiában. Osiris Kiadó, Budapest.

Vargha A. (2000). Matematikai statisztika pszichológiai, nyelvészeti és biológiai alkalmazásokkal. Pólya Kiadó, Budapest. 